\title{
The integrated marketing communication in digital environment: a case study of local radio in Yogyakarta
}

\author{
Maulidina Atikah Rachmawati ${ }^{1,}$ Subhan Afifi ${ }^{2 *}$ \\ 1,2 Universitas Islam Indonesia, Jalan Kalirang KM. 14.5 Ngaglik, Sleman, DIY \\ Corresponding author, email: subhan.afifi@uii.ac.id
}

\author{
Article History \\ Received : $16 / 09 / 2021$ \\ Revised : 08/11/2021 \\ Accepted : 08/12/2021 \\ Published : 31/12/2021
}

\begin{abstract}
The internet and the digitization of media have expanded the ability of mass media to reach the public. Radio is one type of mass media that has developed by utilizing digital technology in the internet era. The development of new technology has expanded radio's ability to reach audiences. The utilization of various innovations through the internet has increased the role of interactive social communication of a radio station. Digitalization has made radio survive during intense competition from multiple types of media in the era of disruption. It is interesting to see how the radio station's integrated marketing communication strategy in the digital environment is changing. This study aims to determine local radio's integrated marketing communication strategy in Yogyakarta in a changing digital environment. This research uses a case study method with in-depth interviews and observation data collection techniques. The results show that radio marketing communication strategies still use various promotional tools with digital technology modifications in a changing digital environment. The case study of Swaragama FM Radio shows that this radio implements an integrated marketing communication strategy which consists of several strategies, namely: (1) Formulating Segmentation, Targeting, and Positioning by adjusting the radio marketing mix character (2) Integrating Advertising and Direct Marketing, (3) Optimizing Sales Promotion and Personal Selling, (4) Strengthening Branding through Public Relations, and (5) Building interaction with the audience through Social Media Marketing.
\end{abstract}

Keywords: integrated marketing communication strategies, radio, listener interest

\section{Introduction}

The internet and media digitization make it easy for the public to access mass media for various purposes, such as seeking information, obtaining entertainment, and expressing opinions in public spaces. Radio is one type of mass media that has developed using digital technology in the internet era. The development of new technologies has expanded radio's ability to reach audiences.

The utilization of various innovations through the internet has increased the role of interactive social communication of a radio station. Radio listeners can interact via websites, email, or other chat 
services through the internet. This interactive communication pattern has enabled radio audiences to be actively involved in the process of broadcasting information. Radio listeners are no longer just broadcast connoisseurs but are also active as informants such as reporters. These advantages strengthen the role of radio in the digital era. Digitization has made radio easier to access and survive during the intense competition for various media types in the age of disruption.

The results of the JAKPAT survey in January 2019 showed that $59 \%$ of respondents were still radio listeners, while the remaining $41 \%$ had not listened to the radio. Radio listeners still exist in the digital era following the changes in the digital environment from conventional radio to streaming radio on smartphones. From a business perspective, the radio industry in Indonesia can still survive and thrive in the digital era (https://jakpat.net/info/).

The radio industry can adapt to the rapidly changing digital environment. Online radio innovation, live streaming, and podcasts are part of radio's efforts to take advantage of technology in the digital era. Radio expands its broadcast reach to reach the public with various technological conveniences. Streaming radio provides listeners with convenience and choice so that it becomes a strategy to maintain the existence of conventional radio amid the development of the digital world. Many radio stations now use the internet to expand their transmitter coverage geographically. Internet-based radio involves streaming media allowing listeners to listen to fascinating audio programs over the internet instantly and can be played back later.

The level of competition for radio stations in big cities to grab the audience's attention is very high. Various technological conveniences, especially radio streaming, have led to new streaming radios. One of the efforts made is to design exciting programs according to the targeted segmentation, following the vision and mission of the radio.

The audience is the most important and main asset that a radio station must protect. For radio stations, listeners are the main parameter of their existence. For this reason, radio stations develop appropriate integrated marketing communication strategies to maintain the presence of radio listeners. The exemplary integrated marketing communication strategy can serve two radio consumers at once, namely radio listeners and advertisers.

Radio stations use an integrated marketing communications strategy to create positive perceptions while keeping, increasing, and retaining listeners. Through promotional programs, radio tries to persuade the audience to keep following the programs that are broadcast and at the same time convince 
advertisers. Marketing communication strategies require careful planning and effective implementation so that radio stations can move dynamically and efficiently to adapt to the times.

Integrated marketing communication (IMC) is developing and implementing various forms of persuasive communication programs to customers and prospective customers on an ongoing basis. The goal of IMC is to influence the target audience's behavior using different tools of promotion such as advertising, direct marketing, sales promotion, and public relations. IMC combines all these disciplines to provide clarity, consistency, and maximum communication impact (Priansa, 2017:101).

Marketing communication in large companies has been designed to be an integrated and comprehensive activity to achieve business goals (Afifi \& Utomo, 2004). Integrated marketing communications are marketing strategies, tactics, and activities that encourage a company to focus its multiple channels on delivering a single, compelling message through various tools in the promotional mix. The message is a message that can attract the attention of the targeted segment and target market. Marketing communication emphasizes two-way interaction. While integrated shows alignment, conformity, or combination in terms of focus, goals, and strategic direction between elements of the promotion mix (sales promotion, advertising, personal selling, direct marketing, and public relations) and between aspects of the marketing mix (product, price, place, promotion). (Chandra, 2002:167).

Marketing communication strategies can combine various existing promotional tools while optimizing the Relationship Marketing concept to achieve the set marketing goals, including responding to unwanted situations during the Covid-19 pandemic (Afifi \& Harianti, 2021). 
The scope of integrated marketing communications can be described as follows:

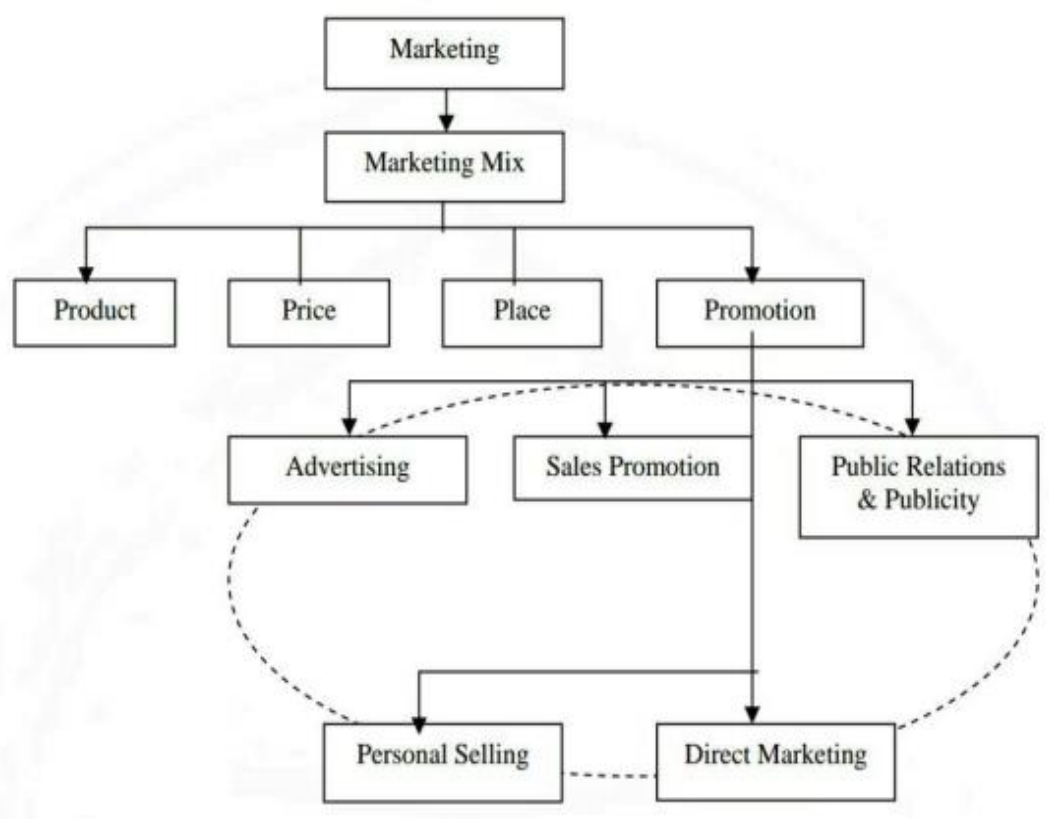

Figure 1. Scope of Integrated Marketing Communication

(Source: Kotler \& Armstrong, 2001: 600)

Advertising delivers the message about a product or service offered through a medium and addressed to some or all of society (Asti Musman \& Sugeng, 2011:9). Based on the picture above, an integrated marketing communication strategy combines existing promotional tools such as advertising, sales promotion, public relations and publicity, personal selling, direct marketing, and other strategies. Advertising on the radio is more efficient and can reach large audiences. In addition, advertising on the radio can create a brand image and symbolic appeal for a company or brand. Radio can also attract consumers' attention through popular advertising (Morissan, 2008: 426).

Sales Promotions are a series of short-term techniques consisting of various promotional activities, including trade performances, contests, samples, displays and displays at the place of purchase, intensive trading, and coupons (Priansa 2017: 122). Sales promotion can also be oriented to marketing intermediaries, namely: retailers, wholesalers, and distributors. In the context of radio advertising, radio stations or advertising agencies usually provide price deal adjustments, incentives, or bonuses that aim to encourage advertisers to advertise on the radio in question (Morissan, 2008: 434).

Public Relations is a program designed to support or protect the image of a business organization or its products. This activity involves organizing communications involving various interested parties 
such as customers, sellers, mass media, employees, shareholders, and the government (Priansa, 2017: 142). In radio, public relations promote broadcast media directly to the public or often called off-airpromotion. In addition, it also utilizes other mass media for publication. In addition to maintaining good relations with audiences, public relations radio also needs press attention (Morissan, 2008: 431).

Direct Marketing is the entire activity carried out to streamline the exchange of goods and services to the target audience through the use of one or more media (direct selling, direct mail, telemarketing, direct-action advertising, catalog selling, cable TV selling, etc.) aimed at generating an immediate response from potential buyers or customers, whether by phone, letter, or personal visit (Priansa, 2017:108). For broadcast media such as radio, direct marketing includes a wide range of activities including database management, direct selling, telemarketing, and direct response advertising using various communication channels such as sending direct letters to customers and potential customers or over the internet, print media, and broadcast media (Morissan, 2008:439).

Personal selling is a face-to-face interaction between individuals aimed at creating, repairing, mastering, or maintaining mutually beneficial exchange relationships with others. Personal selling involves a direct communication relationship between the seller (seller) and consumer (customer) (Priansa, 2017: 220). In the context of radio, personal sales involve direct contact between sellers and buyers of advertising slots, either face-to-face or through telecommunications tools such as telephones. Through this direct interaction, the seller can see and listen to the response or response of the advertiser (Morissan, 2008: 438).

Interactive marketing over the internet is a marketing communication strategy that allows users to perform various functions such as receiving and changing information and images, asking questions, answering questions, and making purchases. The internet is a medium that can carry out all promotional mix elements. In addition to being used for advertising, the internet can also be used to conduct other promotional activities such as sales promotions with quizzes, coupons, contests, and sweepstakes online. Promotion and marketing practitioners also use the internet to direct marketing, personal sales, and public relations activities effectively and efficiently (Morissan, 2008:437).

It is interesting to research how radio marketing communication strategies in the digital environment are changing to attract listeners. Yogyakarta is one of the regions in Indonesia that has many radio stations. Based on data from the Regional Indonesian Broadcasting Commission (KPID) DIY, in 2018, there were 86 radio stations, consisting of 43 FM radios, and the rest are AM radio and community radio(http://kpid.jogjaprov.go.id/). 
The Indonesian Journal of Communication Studies, Volume 14/ Nomor : 2/2021

Page : 105-119

P-ISSN: 1978-323X, E-ISSN: 2685-529

DOI : http://doi.org/10.31315/ijcs.v14i2.5470

According to data from Jogjastreamers in 2020, one of the radios in Yogyakarta with a high level of existence is Swaragama FM Radio. This radio has been on the air since 2000 and managed to occupy the number one top listener and most favorite radio(http://jogjastreamers.com/).

Swaragama FM radio is peculiar in presenting a program nuanced 'Young people.' Currently, Swaragama FM Radio still maintains its target audience, namely young people with an age range between 18-35 years. The name for loyal listeners of Radio Swaragama FM is "Akademia Jogja." Swaragama FM became one of the favorites of Yogyakarta youth radio because it has many creative programs. Radio Swaragama includes Insomnia, Your Friend in the Morning, The Soundtrack Your Life, Sunset Drive, Zona Persada, and Dreamland.

It is interesting to research how The Integrated Marketing Communication Strategy of Swaragama FM Radio in Attracting The Interest of Yogyakarta Listeners. This research aims to find out the integrated marketing communication strategy carried out by Radio Swaragama FM in attracting the interest of Yogyakarta listeners.

Some previous research related to a radio includes Achmad Ambodo (2012) on "Ronggohadi FM Radio Marketing Communication Strategy to Retain Adult Listeners," Rizki Amaliah (2013) on "Fajar FM Makassar Radio Marketing Communication Strategy in Increasing the Number of Advertisers." In addition, Muh Said (2014) has researched "Smart FM Makassar Radio Integrated Marketing Communication Strategy in Increasing the Number of Advertisers," and Anggi Aswan Prinaldi (2017) studied "Kuantan Singingi Local Government Radio Communication Strategy in Attracting Listeners." Aldhi Kurniawan Suswandaru Hardiansyah (2017) has also researched "Integrated Marketing Communication of Broadcasting Radio in Attracting The Interest of Advertisers."

This research offers novelty in analyzing private radio integrated marketing communication strategies in Yogyakarta, known as the student city, by making the millennial youth segment the main segment of listeners. It also emphasizes digital marketing communication strategies that previous research has not widely discussed.

\section{Method}

This study uses a constructivism paradigm that views socially meaningful action through direct observation of social actors in a natural setting. The goal is to understand and interpret how social actors can create and maintain their social world (Suyanto \&Sutinah, 2015: 285). Researchers use qualitative methods, especially case studies. Qualitative research observes behavior and describes it using language 
The Indonesian Journal of Communication Studies, Volume 14/ Nomor : 2/2021

Page : 105-119

P-ISSN: 1978-323X, E-ISSN: 2685-529

DOI : http://doi.org/10.31315/ijcs.v14i2.5470

and words (Trinoviana, 2017: 42). Descriptive research describes the phenomena factually, systematically, and accurately (Muhtadi, 2016: 19).

Researchers collected primary data through in-depth interviews with Swaragama FM radio management informants. Primary data is data obtained directly from the field location, such as shared questionnaires or in-person interviews with research objects (Maryati \& Suryawati, 2006; 110). Researchers interviewed several key informants from Radio Swaragama FM to obtain preliminary data, namely: Mohammad Amirullah (President Director), Bonny Prasetya(Head of Program Director), Dewy Puspo(Head of Marketing), and Cici Priskila (broadcaster). The researchers also collect the data through observation. Observation is the activity of recording phenomena systematically to obtain data and find solutions to a problem (Muhammad Idrus, 2009: 101). Researchers observed a series of activities and programs of Radio Swaragama FM in carrying out integrated marketing. The study also collected secondary data. Secondary data is data in the form of files or documents sourced from other parties (Sugiyono, 2018: 213). Researchers collected secondary data related to Radio Swaragama FM Yogyakarta through books, websites, and online media.

After collecting the data, the researchers perform data analysis. Data analysis is a process of finding and systematically compiling data obtained from field records, interviews, and documentation. The researchers organize data into categories, describing it into units, synthesizing, compiling into patterns, choosing which ones are important and to be learned, and making conclusions so that they are easily understood by themselves and others (Sugiyono, 2011:244). Researchers follow the stages of qualitative research analysis according to Miles and Huberman (1994). The entire research process runs from October 2020 to January 2021. The location or place of this research was conducted on Swaragama FM Radio Station. Location is on Jalan Wisma Kagama Complex Bulaksumur Blok G, Sagan, Sleman Regency, Special Region of Yogyakarta 55281.

\section{Discussion}

Integrated marketing communication is a strategy to align focus, objectives, and strategic direction between elements of the marketing mix (product, price, place, promotion) and between parts of the promotional mix (advertising, direct marketing, sales promotion, personal selling, public relations, interactive marketing) (Chandra, 2002: 167). Integrated marketing communication strategies are related to segmentation, targeting, positioning. Market segmentation divides a market into different buyers based 
on basic needs, characteristics, or behaviors that may require separate products or marketing mixes (Priansa, 2017:41).

Radio management formulates an integrated marketing communication strategy to appeal to listeners by blending various promotional tools. Swaragama FM radio's integrated marketing communication strategy in a digital environment is concerned with companies' segmentation, targeting, and positioning. Here is a comprehensive explanation.

\section{Formulating Segmentation, Targeting, and Positioning}

Market segmentation is essential in understanding broadcasting audiences and program marketing. Market segmentation is an activity to divide or group the audience into more homogeneous boxes with the aim that the company can improve the accuracy of its targets. Berkowitz et al. (2000) in Morissan (2008:167-168) define a market segment as "dividing up a market into distinct groups that (1) have everyday needs and (2) will respond similarly to market action.

Radio Swaragama also grouped segmentation of radio listeners then targeting and positioning. The listener segment is divided into segments A, B, and C. Based on the study results, Swaragama radio station segmentation is the age of 15 to 35 years with status/employment as a student, student, fresh graduate, young executive. Here is an explanation of the research sources on this radio segmentation:

"We are aiming for segment A which is 15-20 years old. This segment is divided into two groups, namely 15-17 years old, teenagers, or middle to high school students. Groups of 18-20-year-olds who are students or groups of young adults. The two have something in common regarding psychographics: love to express, want to stand out, and want to exist. Swaragama needs a segment of listener A especially for off-air shows that require a lot of mass. We also have a B segment listener aged 20-30 years as final semester students or professional workers. This segment has a more passive or quieter character who will interact with adult programs such as talk shows, consultations, etc. Segment C is 30-35 years old and more interested in talking about business. Our marketing targets them as clients." (Interview with President Director of Radio Swaragama, Mohammad Amirullah, November 6, 2020)

Swaragama radio management evaluated opportunities from various alternative broadcasting audience segments. Targeting is choosing the audience segment to focus on program marketing and promotional activities. Before segmenting and targeting, Swaragama FM Radio management conducts adequate research and makes careful considerations. 
Positioning is a thing that displays an image or image to the listener so that the listener can distinguish and get to know the programs owned by other radio stations. Swaragama FM targets the youth segment and strives to be a radio that always accompanies the activities of Yogyakarta youth. This radio then built an image as a young radio with social-economic strata that tend to be middle to upper. One positioning strategy is to create a tagline or slogan. Radio Swaragama's motto is The Soundtrack of Your Life. Swaragama FM wants to color listeners' activities like a soundtrack song in a movie.

Segmentation, targeting, and positioning strategies are the basis for designing the radio marketing mix: product, price, place, and promotion. Products from Swaragama radio include broadcast programs (quizzes, talk shows, news or information) and music (on air). Swaragama FM Radio has daily programs and weekly programs.

Radio Swaragama provides various price variants ranging from regular prices to package prices. Package prices get discounts, compensation, ad creation, and specific discounts. In terms of price, Swaragama FM offers different air time advertising prices depending on the air time products, namely time signals, advertising spots, and adlibs.

Based on researchers' observations, access to Swaragama FM location is very strategic and easy to reach because it is located within the UGM campus and is in the middle of the city, close to highways, schools, shopping centers, offices, cafes, and many more.

While from the aspect of promotion, Swaragama radio has a promotional strategy integrated with various tools such as advertising, direct marketing, sales promotion, personal selling, public relations, and internet marketing. Details of discussion about promotional strategies, especially in the digital environment, are explained in the following sections.

\section{Combining Advertising and Direct Marketing}

Radio Swaragama promotes conventional advertising through other mass media and other promotional tools in the digital era. This radio station tries to combine advertising activities with direct marketing.

To advertise, Radio Swaragama FM utilizes the network of fellow radios who are members of the Swaragama Group, which consists of Swaragama FM 101.7 MHz Yogyakarta, JogjaFamily 100.9 MHz Yogyakarta, and PBS FM 104.8 MHz Serang. All radios that are members of the Swaragama Group become advertising media. 
In addition to promoting Swaragama FM Radio, the media group has become an advertising medium for training service products such as public speaking, master of ceremony broadcaster development, event organizers, and others. Swaragama also holds advertising barter cooperation with print media in Yogyakarta to carry out advertising activities. In addition, Swaragama FM is also actively collaborating with various event organizers, seminars, and entertainment stages in sponsorship and event publications. Swaragama FM's logo and tagline "The soundtrack of Your Life" was then imprinted on various billboards, posters, banners, brochures, and fliers for the event. Usually, these different forms of publication can be found in several malls, restaurants, cafes, and strategic places in Yogyakarta. The researcher also found that Swaragama FM carried out joint advertising activities on various websites such as radioonline.co.id, jogjastreamers, and Gudang.net.

The following is the explanation of the President Director of Swaragama FM, Mohammad Amirullah, as a research resource, regarding the concept of promotion carried out by this radio:

"In principle, radio must have listeners first before advertisers come. We create interesting programs that are not indirectly for advertisers but to be heard by many people. If the listener is a lot, then the ad appears. Advertisers hope that by playing advertisements on Swaragama, many people will hear. The next development is that most advertisers do not only advertise but usually also carry out other promotional activities such as providing product samples and others so that listeners can access their products through quizzes and so on" (Interview with President Director, Mohammad Amirullah, November 6, 2020)

Dewy Puspo, Head of Marketing for Swaragama FM Radio, also confirmed the promotion principles developed, with the following explanation:

"The more we promote, spread various information, carry out branding activities, the more people will become aware that Swaragama is a youth radio with a good program" (Interview with Head of Marketing, Dewy Puspo, October 20, 2020)

Developing direct marketing activities, the marketing division sends program catalogs and advertising rates to the potential advertisers. Usually, this catalog is delivered directly by marketing staff to potential advertisers or sent via email or social media such as Instagram and WhatsApp. Other forms can be presentations related to advertising offers or other cooperation programs to potential advertisers. Direct contact via short message/telephone continued to occur when the client collaborated with Swaragama FM to discuss or inquire about the progress of the agreement. In this case, direct marketing aims to generate an immediate response from potential buyers or customers to stimulate behavior change. 
The Indonesian Journal of Communication Studies, Volume 14/ Nomor : 2/2021

Page : $105-119$

P-ISSN: 1978-323X, E-ISSN: 2685-529

DOI : http://doi.org/10.31315/ijcs.v14i2.5470

This behavior can be tracked, recorded, analyzed, and stored in database form for future Swaragama FM marketing.

\section{Optimizing Sales Promotion and Personal Selling}

Radio Swaragama FM also intensifies sales promotions to attract listeners and advertisers. Sales promotion is oriented to the end-user of a product or service. For example, giving listeners vouchers, coupons, product samples, discounted prices, quiz prizes, and others. There are various forms of promotion given to listeners, such as cash, meal vouchers, shopping vouchers, credit, movie tickets, picnics together, and eating together with the announcer. Swaragama FM carried out the sales promotion, attracted listeners' interest, and built listener interactivity. As explained by the following research informants:

"Sometimes Swaragama also invites listeners to gather with Swaragama broadcasters by holding certain quizzes." (Interview with Head of Marketing, Dewy Puspo, October 20, 2020)

The Sales promotions programs give special price discounts for advertisers with certain conditions. Sales promotion programs are designed in such a way as to attract potential advertisers to advertise on Swaragama FM.

In addition to sales promotion, Swaragama also optimizes Personal Selling activities. It takes the form when a marketing staff of Swaragama radio meets with a prospective advertiser or sponsor by carrying out person-to-person communication. Direct meetings with clients have usually discussed advertising programs, terms, and payment conditions. Further contact can be followed up via telephone, email, WhatsApp, or other social media. The following is an explanation of research informants about personal selling that was carried out:

"In Personal Selling activities, there is a CAPO process (Contact, Appointment, Proposal, Order). Contact or contacting prospective clients is the first step that continues to meet with clients (appointments). The marketing staff then provides a proposal containing prices, benefits, and negotiation. When negotiations reach an agreement, the client places an Order. If the ad has been broadcast, there is an evaluation of client satisfaction, criticism, and suggestions." (Interview with Head of Marketing, Dewy Puspo, October 20, 2020).

\section{Strengthening Branding through Public Relations}

Radio Swaragama FM tries to build branding and strengthen a positive image through Public Relations activities. One of them is holding various off-air promotion activities and building good relations with the internal and external public. 
The marketing develops collaboration with other mass media and cooperation with various universities in Yogyakarta, and other media, for example, by collaborating with radios that are members of the Swaragama Group such as Radio JogjaFamily, $100.9 \mathrm{MHz}$ in the city of Yogyakarta and PBS FM 104.8 MHz in the city of Serang.

The following is an explanation of research informants regarding collaboration with universities and other institutions as part of Public Relations activities:

"Cooperation with campuses is usually in the form of sponsorship. We select incoming proposals to invite cooperation. We see how effective the event is, its many views, and its scope. We broadcast advertisements for their events on Swaragama radio, and our logos were posted in various publications on campuses. We hope that our branding will be better, viewers will increase, and people will be more aware of Swaragama. In addition to the campus, we also establish good relations with other institutions. We actively participate in various events in Jogja such as FKY, ARTJOG, Ngayogjazz, and others so that more and more Swaragama logos are spread everywhere. (Interview with Head of Marketing, Dewy Puspo, October 20, 2020)

Swaragama also develops various programs outside of radio to strengthen branding through multiple pieces of training and event organizers. The following is the informant's explanation:

"Swaragama FM has a line of business outside the radio business, namely Swaragama Training Center (STC), SPRO! (Event Organizer) and many other activities. We hope that our brand will be everywhere and indirectly, people will know Swaragama. We also hold various MICE (Meeting, Incentive, Convention, and Exhibition) events (Interview with the President Director, Mohammad Amirullah, November 6, 2020)

\section{Build interaction with listeners through social media marketing}

Swaragama FM conducts interactive marketing through Twitter, Facebook, Whatsapp, and Instagram. Swaragama FM invites its listeners to be active with the broadcasters on-air social media. Swaragama FM tries to build interaction with its listeners in every post on its social media.

Posts on social media contain exciting information about Swaragama, such as quizzes about program themes, Swaragama visits, live streaming with specific artists or figures, and promoting events organized by Swaragama FM. In addition to this, it contains the promotion of training classes at the Swaragama Training Center, MA (STC).

Swaragama FM greets the Jogja Academies' daily lives as listeners through postings on social media. Likewise, when broadcasting on-air, postings on social media become interactive communication media for listeners, such as inviting listeners to tell stories in the comments column, leaving greetings, asking for specific requests, or commenting on the topic being discussed. 
The Indonesian Journal of Communication Studies, Volume 14/ Nomor : 2/2021

Page : 105-119

P-ISSN: 1978-323X, E-ISSN: 2685-529

DOI : http://doi.org/10.31315/ijcs.v14i2.5470

\section{Conclusion}

The results show that in a changing digital environment, radio marketing communication strategies still use various promotional tools that have been known in the study of communication science with modifications using digital technology.

The case study of Swaragama FM Radio shows that this radio implements an integrated marketing communication strategy which consists of several strategies, namely: (1) Formulating Segmentation, Targeting and Positioning, (2) Integrating Advertising and Direct Marketing, (3) Optimizing Sales Promotion and Personal Selling, (4) Strengthening Branding through Public Relations, and (5) Building interaction with Social Media Marketing.

Segmentation, targeting, and positioning are formulated according to the marketing mix: product, price, place, and promotion. Specifically, promotion is managed in an integrated marketing communication strategy by combining advertising and direct marketing. This radio manages advertising by utilizing various other radios members of the Swaragama Group and running sponsorship partnerships. The marketing division also runs direct marketing to communicate with potential advertisers, either directly or through various media.

Swaragama FB builds branding through public relations by establishing good relations with other mass media, universities, and institutions through various off-air events in Yogyakarta. In addition, Swaragama FM also optimizes sales promotion by providing attractive promotional offers to listeners and potential advertisers. Radio stations also carry out personal selling activities through the CAPO (Contact, Appointment, Proposal, and Order) process. Swaragama FM also conducts interactive marketing by utilizing swaragamafm.com and social media Facebook, Twitter, and Instagram.

\section{References}

Afifi, S \& Hariyanti, P. (2021). The Relationship Marketing Communication Strategy During the Covid19 Pandemic: A Case Study of Islamic Schools in Yogyakarta. 596(Jcc), 235-240.

Afifi, S \& Utomo, HJN. (2004). Strategi Komunikasi Pemasaran Usaha Kecil Menengah (UKM) Di Kabupaten Bantul dan Kulon Progo Yogyakarta. Jurnal Ilmu Komunikasi. Volume 2, Nomor 2, Mei - Agustus 2004

Aldhi, KS. (2017). "Komunikasi Pemasaran Radio Penyiaran Dalam Menarik Minat Pemasang Iklan (Studi Deskriptif Kualitatif Terhadap Lembaga Penyiaran Swasta Radio Metta 104.7 FM di Solo). Skripsi Program Studi Ilmu Komunikasi Fakultas Ilmu Sosial dan Humaniora Universitas Islam Negeri Sunan Kalijaga Yogyakarta

Ambodo, A. (2012) "Ronggohadi FM Radio Marketing Communication Strategy to Retain Adult 
Listeners." Thesis of Communication Science Study Program of Faculty of Dawah IAIN Sunan Ampel Surabaya

Desi, YP \& Helena, M. (2017). Implementasi Integrated Marketing Communication (Imc) Dalam Memperkuat Brand Swaragama Group Yogyakarta. Jurnal Ilmiah Manajemen Informasi dan Komunikasi. Volume 1 Nomor 1 September 2017

Gregorius, C. (2002). Strategi dan Program Pemasaran. Edisi 1. Andi: Yogyakarta

Idrus, M. (2009). Metode penelitian Ilmu Sosial. Yogyakarta: PT. Gelora Akasara Pratama

Jannatin, NM. (2018). "Strategi Pemasaran Prima Radio Surabaya". Skripsi Program Studi Ilmu Komunikasi Fakultas Dakwah dan Komunikasi Universitas Islam Negeri Sunan Ampel Surabaya, 2018

Kotler \& Amstrong. (2001). Prinsip-prinsip pemasaran. Edisi ke 12, Jilid 1. Jakarta: Erlangga

Kotler \& Armstrong. (2001). Dasar-Dasar Pemasaran. Jilid 2. Jakarta: Penerbit Erlangga

Maryati, K \& Suryawati, J. (2006). Sosiologi. Jakarta: Esis

Miles, MB. \& Huberman, AM. (1994). An Expanded Sourcebook: Qualitative

Muhtadi, AS. (2016). Pengantar Ilmu Jurnalistik. Bandung: Simbiosa Rekatama Media

Morissan, AM. (2008). Manajemen Media Penyiaran. Jakarta: Prenada Media Group

Anggi Aswan Prinaldi. "Strategi Komunikasi Radio Pemerintah Daerah Kuantan Singingi Dalam Menarik Minat Pendengar". Skripsi Program Studi Ilmu Komunikasi Fakultas Dakwah dan Komunikasi Universitas Islam Negeri Sultan Syarif Kasim Riau Pekanbaru, 2017

Musman, A \& Sugeng WA. (2011). Marketing Media Penyiaran Bukan Sekedar Jual Kecap. Yogyakarta: Atma Pustaka

Rahmani, P. (2019). "Komunikasi Pemasaran Terpadu Radio Swasta Di Yogyakarta Dalam Memperoleh Pengiklan Dengan Konteks B2B (Studi Kasus Radio Swaragama FM Dan Radio Geronimo FM)". Skripsi Program Studi Ilmu Komunikasi Fakultas Psikologi Dan Ilmu Sosial Budaya Universitas Islam Indonesia Yogyakarta.

Priansa, DJ. (2017). Komunikasi Pemasaran Terpadu. Bandung: Pustaka Setia

Rangkuti, F. (1997). Riset Pemasaran. Jakarta: PT Gramedia Pustaka Utama

Setiawan. W. (2017). "Strategi Positioning Radio Swaragama 101.7 FM Positioning Strategy on 101.7 Swaragama FM Radio". Skripsi Program Studi Ilmu Komunikasi Fakultas Ilmu Sosial Dan Ilmu Politik Universitas Muhammadiyah Yogyakarta 
The Indonesian Journal of Communication Studies, Volume 14/ Nomor : 2/2021

Page : 105-119

P-ISSN: 1978-323X, E-ISSN: 2685-529

DOI : http://doi.org/10.31315/ijcs.v14i2.5470

Sugiyono. (2011). Metode Penelitian Kuantitatif, Kualitatif dan R\&D. Bandung: Alfabeta

Sugiyono. (2018). Metode Penelitian Pendidikan: Pendekatan Kuantitatif, Kualitatif, dan R\&D. Bandung: Alfabeta

Sulaksana, U. (2003). Integrated Marketing Communication. Yogyakarta: Pustaka Pelajar

Suyanto \& Sutinah. (2015). Metode Penelitian Sosial: Berbagai Alternatif Pendekatan. Jakarta: Prenada Media

Terence, AS. (2004). Periklanan dan Promosi: Aspek Tambahan Komunikasi Terpadu. Jilid 2. Jakarta: Erlangga

Ulya, A. (2019) "Strategi Komunikasi Penyiar Radio Dakwah Islam Semarang Dalam Meningkatkan Jumlah Pendengar”. Skripsi Program Studi Komunikasi dan Penyiaran Islam Fakultas Dakwah Institut Agama Islam Negeri (IAIN) Salatiga

\section{Website:}

https://databoks.katadata.co.id/f (accessed on $3^{\text {rd }}$ March 2020)

https://jakpat.net/info/ (accesed on $3^{\text {rd }}$ March 2020)

https://id.wikipedia.org/wiki/Daftar_stasiun_radio_di_Daerah_Istimewa_Yogyakarta (accesed on 3

March 2020)

https://swaragamafm.com (accesed on $1^{\text {st }}$ November 2020)

https://radioonline.co.id/( accesed on $30^{\text {th }}$ Desember 2020)

www.instagram.com/swaragamafm/. (accesed on $22^{\text {th }}$ December 2020)

https://twitter.com/swaragamafm. (accessed $22^{\text {th }}$ December 2020)

http://jogjastreamers.com/ (accesed on $19^{\text {th }}$ February2021)

http://kpid.jogjaprov.go.id/ (accesed on $3^{\text {rd }}$ March 2020) 